\title{
Prosody and versification systems of ancient verse
}

\author{
Maria-Kristiina Lotman \\ Department of Germanic and Romance Philology, University of Tartu, \\ Ülikooli St. 17, Tartu, Estonia \\ e-mail: maria.lotman@mail.ee
}

\begin{abstract}
The aim of the present study is to describe the prosodic systems of the Greek and Latin languages and to find out the versification systems which have been realized in the poetical practice. The Greek language belongs typologically among the mora-counting languages and thus provides possibilities for the emergence of purely quantitative verse, purely syllabic verse, quantitative-syllabic verse and syllabic-quantitative verse. There is no purely quantitative or purely syllabic verse in actual Greek poetry; however, the syllabic-quantitative versification systems (the Aeolian tradition) and quantitative-syllabic versification systems (the Ionian tradition) were in use. The Latin language, on the other hand, has a number of features, which characterize it as a stress-counting language. Since at the same time there exists also the opposition of short and long syllables, there are preconditions for the syllabic, accentual and quantitative principle, as well as for the combinations of these. The Roman literary heritage shows examples of purely accentual, syllabic-quantitative, quantitative-syllabic, as well as of several other combinatory versification systems.
\end{abstract}

\section{Introduction}

There are quite many studies which treat the prosody of ancient verse, but the opinions differ even in the most basic questions. Already the term 'prosody' has different meanings for different scholars. Roughly speaking, there are two main kinds of approaches. The first (so-called linguistic approach) treats prosody as certain elements which are superimposed on phonemes (typically, such elements are stress, force 
and pitch; another term used for them is suprasegmentals) ${ }^{1}$. These elements are paradigmatically opposed to one another, e.g., high vs low pitch in identical environment (Allen 1973: 6), but they can also have secondary values which are defined syntagmatically (Hogg, McCully 1987: 62). The object of the latter treatment (so-called literary prosody) is versification: verse forms, rhythms and patterns. E.g., James Graig La Drière (1943: 455) defines prosody as the general term for analysis of the rhythmic structure of sound in speech, especially in verse. W. S. Allen (1973: 12) offers a kind of synthesis of the above-mentioned treatments, claiming that force, pitch and duration are the most basic features of phonation, as well as the most important constituents of versification which function prosodically in the most languages.

The leading scholars on ancient verse, who usually proceed from the literary approach, generally discuss not the prosodic system, but only separate features of it. Thus, e.g., D. S. Raven in his study on Latin verse, describes in the chapter devoted to prosody the rules of stress and quantity, the law of iambic shortening, elision and hiatus (1965: 22-30), and Martin L. West in his monograph on Greek metre (1982: 7-17), in addition to the rules of quantity, pays also attention to a number of prosodic features. But there is no treatment of how these features join into a system and what is the typological place of the analysed languages among other languages. As for the versification systems of ancient verse, the leading treatments of ancient verse, as a rule, provide no special analysis of these; the Western scholars often regard them implicitly and as a part of prosody.

The present study proceeds from the typology of versification systems, where versification systems are treated as a correspondence between metre and prosody of natural languages, a correspondence that proceeds from metrics and creates the prosody of versification, transforming at the same time the prosody of natural language (Lotman 1998: 1858). The list of the main versification systems is as follows: (1) purely quantitative verse, where only the number of quantities is fixed, but not their positions (there have remained no examples of such verse, however, some of the Sanskrit verses resemble this type); (2) syllabic verse, where metrically relevant unit is the syllable (e.g. Indo-European verse); (3) accentual verse, where the accent is metrically relevant; (4) free verse, where metrically

${ }^{1}$ Cf., e.g., Trubetzkoy 2000, Lehiste 1970, Otake \& Cutler 1999, Hogg \& McCully 1987. 
relevant unit is the phrase; (5) syllabic-quantitative verse, where the number of syllables is fixed; quantity is governed by syllabics (e.g. the Aeolian verse, the Vedas); (6) quantitative-syllabic verse, where both the number and the position of quantities is regulated; (7) accentualsyllabic verse, where the versification is determined both by syllabics and accents, but accents dominate the syllabics; (8) syllabic-accentual verse, where the number of syllables is fixed and accents are subject to regulation; (9) accentual-syllabic-quantitative verse, where all the three principles are applied; (10) quantitative-accentual-syllabic verse, where regulation applies primarily to quantity, but also the configuration of accents; the number of syllables is governed by quantity (Lotman 1998: 2074).

The aims of the present study are a) to describe the prosodic systems of the Greek and Latin languages; b) in accordance with the prosodic systems of given languages, to establish the versification systems for which Greek and Latin have a natural basis and determine which of these systems have been realized in the poetical practice.

\section{Prosodic system of the Greek language}

The most important features of the Greek language are the following.

(1) The elementary prosodic unit or prosodeme is not a syllable, but a durational unit - mora. Consequently, Greek is typologically a mora-counting language, where prosodemes are distinguished by pitch (cf. Trubetzkoy 2000: 211).

(2) In Greek, both vowels and consonants can be prosodically significant. Syllables can be unarrested (i.e. open syllables with short vowels, e.g. $\sigma \hat{\varepsilon}$ ), as well as arrested, either orally (i.e. closed syllables with short vowels, e.g. $\delta$ ós) or thoracically (i. e. syllables with long vowels or diphthongs, e.g. $\gamma \hat{\eta}$, cf. Stetson 1951, Allen 1973: 65, 203) ${ }^{2}$. There can also occur the so-called hypercharacterization, i.e. the syllable is arrested both thoracically and orally, cf. e.g. the subjunctive medio-passive form $\pi \alpha \imath \delta \varepsilon v \omega v \tau \alpha t$.

\footnotetext{
${ }^{2}$ The author of the present study proceeds from one of the many interpretations of the syllabic structure, the so-called motor theory, according to which the syllabic pulse can be arrested by thoracic muscles or oral (consonantal) articular stroke, i.e. the syllables $\sim \mathrm{V}$ and $\sim \mathrm{VC}$ are both arrested, the former thoracically, the other orally (Stetson 1951). Mihhail Lotman points out that a phonological syllable does not necessarily coincide with a prosodic syllable, cf. the clauses (6c) and (6d) of the present chapter.
} 
(3) The syllable can be heavy, light or anceps. The syllable is heavy if it is orally or thoracically arrested, otherwise it is light. Quantities are determined by subjective duration, since objectively e.g. the syllables $\pi \eta$ - and $\pi \varepsilon \rho$ - were not isochronous, but they were perceived as metrically equivalent heavy syllables, which were opposed to light syllables. Accordingly, the syllables $\pi \eta-, \pi \varepsilon v-, \pi \eta \gamma-$ and $\pi \varepsilon \rho \kappa^{-}$-were equivalent to each other and opposed in quantity to the light syllable $\pi \varepsilon$-; while at the same time there was no actual relationship $2: 1$ between short and long durations (cf. also Kuryłowicz 1960: 393).

(4) There is no reduction of unstressed syllables (when vowels meet, an elision of syllables can take place, but such phenomenon characterizes stressed syllables as well).

(5) The nature of accent is melodic, not dynamic, i.e. an accented syllable differs from unaccented ones not by force, but by pitch. There are three types of accent: (a) the so-called acutus (ókvs) which can occur both on heavy and light syllables, but only on the last three syllables, and on the antepenultimate syllable it can occur only if the final syllable of the word is light, as in e.g. $\pi \delta_{\lambda} \cos (\text { war })^{3}$; (b) gravis ( $\beta \alpha \rho v \varsigma)$ which replaces acutus in the case when the word is followed by another word without a punctuation mark, cf. e.g. $\gamma \varepsilon \omega \rho \gamma o ́ s$ (farmer) and $\gamma \varepsilon \omega \rho \gamma \dot{s} s \quad \alpha \gamma \alpha \theta \dot{s} s$ (a good farmer); and (c) circumflexus ( $\pi \varepsilon \rho \imath \sigma \pi \omega \mu \varepsilon v o \varsigma)$ which can occur on the last two syllables, but only on a syllable that contains a long vowel or diphthong, and it can occur on the penultimate syllable only if the final syllable is light, e.g. $\delta \hat{\omega} \rho o v$ (gift). Roman Jakobson formulates this rule more clearly: "The span between the accented and the final mora cannot exceed one syllable" (Jakobson 1962: 263).

(6) When vowels meet, several options are possible (West 1982: 10-15):

a. elision, e.g. the disappearance of the short final vowel before the initial vowel of the following word, e.g. $o \delta^{\prime} \alpha \hat{v}=o v \dot{v} \dot{\varepsilon} \alpha \hat{v}$;

b. correption, where a long vowel or a diphthong at the word-end is shortened before the initial vowel of the next word; this phenomenon is characteristic, above all, to early epic and elegy;

c. synizesis or synecphonesis, i.e. two or more vowels which initially belong to separate syllables, are amalgamated into one heavy syllable;

\footnotetext{
${ }^{3}$ There are some exceptions to this rule, cf. e.g. Allen 1973: 237.
} 
d. consonantalization of 1 and $v$ between a consonant and another vowel in the same word, e.g., $A \rho \theta \mu \imath \alpha \dot{\delta} \delta \omega$ in Arcilochos 29.2;

e. hiatus, in which case both vowels retain their initial values. Hiatus is usually avoided with elision, crasis or so-called movable $v(v$ $\dot{\varepsilon} \varphi \varepsilon \lambda \kappa v \sigma \tau \imath \kappa o ́ v)$ which is added to the ending $-\sigma \iota$ of dat. pl., as well as to the affix $-\sigma l$, the endings $-\varepsilon$ ja $-\sigma l$ of 3 . sg and $p l$. of verb, the form $\dot{\varepsilon} \sigma \tau i$, adverb $\pi \alpha v \tau \alpha \dot{\alpha} \pi \alpha \sigma \imath$ and numeral $\varepsilon i ́ \kappa o \sigma l$. Hiatus is occasionally admitted by epic and elegiac poets.

It is important to mention that in the early Middle Ages fundamental phonological changes took place, one of the most significant changes being the replacement of the melodic accent by the dynamic one. As a result, the distinction between long and short vowels ceased to exist (cf. Roman Jakobson's law that if an independent co-existence of dynamic accent and quantity evolves, one of these elements disappears from the phonological system; Jakobson 1969: 24).

\section{Versification systems in Greek poetry}

Prosodic features determine which versification systems may evolve on the basis of a given language. Thus, the above-mentioned features indicate that the Greek language which typologically belongs to the mora-counting languages, could meet the conditions for the evolvement of purely quantitative verse, where structure is determined only by the number of moras in a verse; the conditions for evolvement of purely syllabic verse, where the only determined factor is the number of syllables in a verse; and their combinations: quantitative-syllabic verse, where in addition to the number of moras also their configuration is considered; and syllabic-quantitative verse, where the number of syllables is fixed and quantity is subject to the syllabics (Lotman 1998: 2059-2062). The accentual principle has no role in versification, since this kind of melodic accent that is characteristic to Greek, can not create rhythmical oppositions.

In actual Greek poetical practice the purely quantitative and the purely syllabic versification systems are not to be found, however, there do exist the syllabic-quantitative versification system (the Aeolian tradition) and quantitative-syllabic versification system (the Ionian and Dorian tradition). 


\subsection{The syllabic-quantitative versification system}

The Aeolian verse has some features obviously in common with the Indo-European verse: the strict number of syllables (a heavy syllable cannot be replaced by two light syllables, and vice versa); the longer verse is divided into shorter cola (cf. the caesura of the Indo-European verse); in the first two positions of a verse the quantity is irrelevant which is most probably a relic of the Indo-European verse. There are three possibilities for filling the positions: a heavy syllable, a light syllable or a syllable with irrelevant quantity or anceps. There are about 20 basic cola, which are joined into verses and strophes. The most important of these are the so-called glyconic $(x \times-\cup \cup-\cup-)$ and pherecratean $(x \times-\cup \cup--)$, the former of which we shall now consider in more detail.

In the case of this kind of structure we need to distinguish between two principles of versification: a) the syllabic principle which regulates the number of syllables in a verse; b) the quantitative principle which regulates the configuration of durations and is governed by the syllabic principle (Lotman 1998: 2061-2062). When we mark heavy positions as A (the denotation of an abstract metrical element), light positions as B and metrical delimitators as $\&$, ${ }^{4}$ we get the following structure: \&AAABBABA\&. Here, the following syllabic-quantitative correspondence rules apply:

(1) To the position A corresponds one heavy syllable.

$\mathrm{A} \rightarrow-$

(1a) To the position A1 corresponds one heavy or one light syllable, but the latter can occur only if the position $A_{2}$ is filled with the heavy syllable (West 1982: 30).

$$
\begin{aligned}
& \mathrm{A}_{1} \rightarrow- \\
& \mathrm{A}_{1} \rightarrow \cup / \ldots-
\end{aligned}
$$

(1b) To the position A2 corresponds one heavy or one light syllable, but the latter can occur only if the position $A_{1}$ is filled with the heavy syllable (West 1982: 30).

$\mathrm{A}_{2} \rightarrow-$

$\mathrm{A}_{2} \rightarrow \cup /-\ldots$

(2) To the position B corresponds one light syllable.

$\mathrm{B} \rightarrow \cup$

\footnotetext{
${ }^{4}$ The hierarchy of metre will be marked with additional delimitators.
} 
E.g. Sappho, 94. $3 \mathrm{ff}:^{5}$

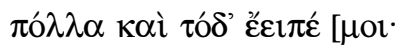

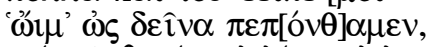

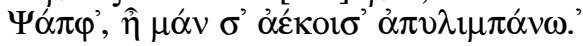

\subsection{Quantitative-syllabic versification system}

The Ionian verse is characterized by the fixed number of moras and the regulated configuration of durations, but at the same time the number of syllables is variable. Namely, the Ionian quantitative-syllabic verse tradition is governed by a principle according to which in certain positions a heavy (i.e. dimoraic) syllable can be replaced with two light (i.e. monomoraic) syllables. There are two kinds of replacements: contraction which is the filling of two light positions with one heavy syllable (e.g. in dactylic measures), and resolution which is the filling of one heavy positions or princeps with two light syllables. At the same time, there exist not only positions allowing two variations, in which case the position is filled either with one heavy syllable or two light syllables, but also positions allowing three variations, the socalled ancipitia, which can be filled by a light syllable which can then be replaced by a heavy syllable, which, in its turn, can be resolved into two light syllables $(\vec{v})$.

There are also other major differences between the Aeolian and Ionian verse structure. While in Indo-European, as well as in the Aeolian versification, the smallest metrical unit was the whole line, in which light and heavy syllables alternated irregularly, then in the Ionian versification this alternation acquired a regularity, where the elementary metrical unit was a verse foot. There were feet consisting of three moras, (iambus $\cup-$, trochee $-\cup$, tribrach $\cup \cup \cup$ ), four moras (dactyl $-\cup \cup$, anapaest $\cup \cup-$, spondee --, prodeleusmaticus $\cup \cup \cup \cup$ etc) and five moras (creticus $-\cup-$, bacchius $\cup--$ etc) - thus, almost all the combinations of syllables were taken into use. Shorter, trimoraic combinations formed metrons in twos and the name of a metre depended on the number of metrons used to form a verse. The

\footnotetext{
${ }^{5}$ Verses can be formed also by the internal expansion of cola; usually it is done with choriambic or dactylic structures. Thus, in the case of 94.3-4 the metre is glyconic, but in 94.5 the glyconic has been expanded with a dactyl resulting in the structure $x \times-\cup \cup-\cup \cup-\cup-$.
} 
iambic verse with four feet was called, accordingly, iambic dimeter; the one with six feet was called iambic trimeter, etc. Although the number of verse feet was fixed, the number of syllables was not: it was bound to vary due to the equivalence of two light syllables with one heavy. Consequently, e.g. in a hexametrical verse there can occur 12-17 syllables, depending on how many contractions have taken place in a given verse. The number of moras was, however, fixed.

The structure of hexameter can be presented in the form of the following scheme (Lotman 1998: 2059-2060) ${ }^{6}$ :

$\& \& A B \& A B \& A B \& A B \& A B \& A B \& \&$

whereby the following correspondence rules apply:

(1) One heavy syllable corresponds to position A.

$\mathrm{A} \rightarrow-$

(2) One heavy syllable or the sequence consisting of two light syllables corresponds to position B.

$\mathrm{B} \rightarrow-$

$\mathrm{B} \rightarrow \cup \cup$

(2a) One syllable with an irrelevant quantity corresponds to position B6.

$\mathrm{B} 6 \rightarrow \times$

${ }^{6}$ Of course, there exist other possible ways of description. E.g., Morris Halle has proposed the following scheme: SWSWSWSWSWSS, where to symbol S (strong) corresponds one heavy syllable, but to symbol W (weak) one heavy or two light syllables. The substantial difference is here only in the last foot, which is presented with the structure SS. The main disadvantages of such description are: a) S does not signify the heavy syllable only, but also the strong position, due to this, it is not a suitable symbol, in principle, to signify the last position; b) the scheme does not reflect the quantitative irrelevance of the last syllable. On the other hand, it is possible to depict the structure of hexameter with a following scheme:

$\& \& A B B \& A B B \& A B B \& A B B \& A B B \& A B(B)^{-}$,

where one heavy syllable corresponds to the symbol A, while one light syllable corresponds to the symbol B. But in such case the formulation of correspondence rules may cause certain problems (Lotman 1998: 2060). Martin L. West (1982: 35) prefers to describe hexameter as a metre consisting of two cola, the parts of which -uv-uv(hemiepes, symbol D), x-uv-uv-- and -u-uv-un-- (paroemiacus) can also occur independently. Thus, M. West presents the following pattern of hexameter: $\mathrm{D}: \bar{\sim} \sim \mathrm{D}-\|$. Although this pattern is based on the historical development of hexameter, it has several disadvantages. Namely, the formulation of correspondence rules is very difficult, and the rhythmical analysis is more complicated as well: even in M. L. West's own treatment it is only declarative and in actual analysis the units of descriptions are still verse feet, not cola. 
Thus, the constancy of the metrical structure is determined by the quantitative principle ${ }^{7}$ and the rhythmical variety depends on the syllabic principle, whereby the latter is subject to the former. E.g., Homeros, Iliad 2. 35-36:

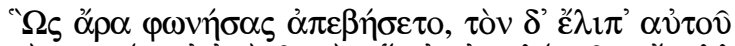

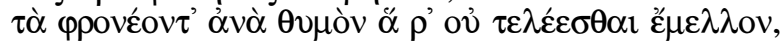

where the first line is composed of 16 syllables, the second one of 17 syllables.

The Dorian verse tradition is even more interesting: here we can find both syllabic-quantitative and quantitative-syllabic verse feet, where resolutions and contractions take place. While in the case of the Ionian versification the smallest symmetrical unit is verse foot and verse line is a symmetrical chain of verse feet, then in the case of the Dorian verse the symmetry often appears only on the strophical and hyperstrophical level. Especially common are the triadic compositions, where the metrically equivalent strophe and antistrophe $(\sigma \tau \rho \circ \varphi \eta \dot{\eta}, \alpha v \tau \iota \sigma \tau \rho \circ \varphi \hat{\eta})$ are followed by a different metrical form, socalled epode ( $\dot{\varepsilon} \pi \omega \delta \delta \zeta$, cf. also West 1982: 47). Typologically, however, this kind of versification should be defined as quantitativesyllabic, since due to the occurrences of resolutions, contractions, anaclasises, etc, the syllabics is governed by quantity.

E.g., Ibykos, 282. 10-22, where the strophe and antistrophe are metrically equivalent, but the structure of the epode is different:

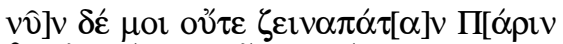

strophe

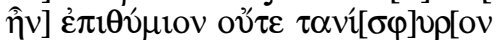

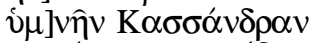

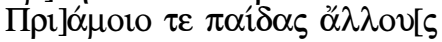

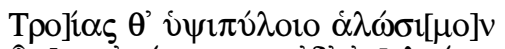

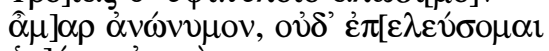

antistrophe

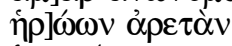

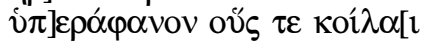

${ }^{7}$ Since the final syllable is anceps, then, in strict sense, also the number of moras is subject to a slight variation, i.e. 23-24 moras per verse. However, most of the metricians treat the verse boundary as a potential prolongation of a syllable, and so, even a light syllable at the end of a line is dimoraic. Cf. also the example below (Hom. I1. 2. 35-36), where the first line ends with a heavy syllable, but the second with a light one. 


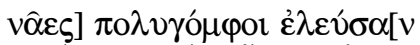

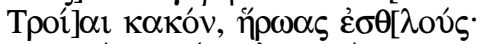

epode

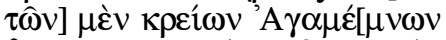

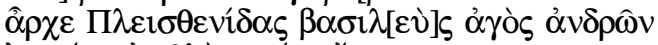

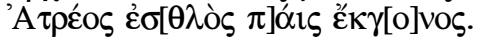

\section{The prosodic system of the Latin language}

The prosodic system of Latin is considerably more problematic than the prosody of Greek. There is no general agreement on the nature of Latin accent. The basic question is: was it melodic, as that of Greek, or dynamic? There is a certain disagreement between verse researchers and phonologists. There are many scholars (cf., e.g., Boldrini 1999: 3-4, but also most French metricians; Allen 1973: 151), who have no doubt that the nature of Latin accent resembled that of Greek. At the same time the phonologists (cf., e.g., Palmer 1954: 211; Niedermann 1945: 20-25; Allen 1973: 151-154) tend to think that at least during some periods Latin accent had to be dynamic, i.e. based on intensity. The latter viewpoint is grounded on copious evidence provided by historical phonology. Namely, the early literary Latin reflects certain changes which had to take place in prehistoric Latin. First, there are many words which show the change or loss of the vowel (syncope) in the second syllable. The timber of a vowel has changed in words sustineo (cf. teneo), conficio (cf. facio) etc; the loss of the vowel can be noticed in reppuli (*repepuli), quindecim (*quinquedecim), valde (valide) (Niedermann 1945: 22). Secondly, in certain short words (ill', nemp', quipp', satin') the final -e disappeared in speech, enclitical forms like 's, 'st pro es and est evolved, as well as the contractions percussust $=$ percussus est, sis $=$ si vis, malo, mavolo= magis volo - all this gives evidence of the tendency to the reduction of unaccented syllables (West 1982: 186-187). Such features indicate that the prehistoric Latin had a dynamic accent, because the loss of unaccented syllables is not typical to languages with a melodic accent (cf. the prosodic system of Greek).

Presumably, the prehistoric accent was fixed on the first syllable. According to the belief of many scholars, the position of the accent on the first syllable as well as its dynamic nature changed in the course of language evolution. In longer words a secondary accent evolved which anticipated an accent on the first syllable of the following word, according to the formula $\underline{\sim} x \mid \dot{x} \ldots$ or $\stackrel{\sim}{\sim} \sim x^{\prime} \mid \dot{x} \ldots$ By the historical times 
such accent had become primary, and, in its turn, generated a secondary accent to longer words: commilitiónes, emòriebátur (West 1982: 186). The fact that there is no considerable reduction in classical Latin has sometimes led to the conclusion that during the classical period the melodic component may have become prevalent over the exspiratory (intensity) and thus, the nature of accent became melodic ${ }^{8}$ (Niedermann 1945: 20-25) which is supported, e.g., by the statement of the grammarian Sergius, cited by Varro: "natura vero prosodiae in eo est, quod aut sursum aut deorsum; nam in vocis altitudine omnino spectatur adeo, ut si omnes syllabae pari fastigio vocis enuntietur, prosodia sit nulla" (Grammatici Latini 4. 525. 21-22), but also Cicero: "ipsa enim natura, quasi modularetur hominum orationem, in omni verbo posuit acutam vocem ${ }^{10 "}$ (Orator 18. 57).

Nevertheless, such arguments in favour of a melodic accent are not irrefutable, because the influence of the Greek culture, incl. Greek philology, continued to be immense, and it is quite clear that the prosodic terms of Sergius, Cicero and others had been borrowed from Greek: accentus for $\pi \rho o \sigma \omega \delta i \alpha$, acutum for $\hat{\jmath} \xi v$, grave for $\beta \alpha \rho v$; moreover, there were attempts to apply the whole complicated system of Greek accentuation to Latin (cf. e.g. Grammatici Latini 5. 126). But it is hard to believe that Latin would have developed a melodic accent that in detail corresponded to the Greek accent, thus, it would be more logical to assume that Latin grammarians only with great precision applied the Greek system to the description of Latin (Allen 1973: 151; Palmer 1954: 311-312). The fact that in popular Latin syncopes (e.g. pedicaut pro pedicavit, maldixit pro maledixit) can be found already in the 1 st century $\mathrm{AD}$, is also important: i.e., the accent in popular Latin was dynamic.

Consequently, although there are more arguments in favour of dynamic accent in classical Latin, we can not completely exclude the

${ }^{8}$ Such viewpoint is not supported by several scholars either. E.g., according to W. Sidney Allen (1973: 152) it is unlikely that Latin developed a melodic accent, which only after a few centuries was again replaced by a dynamic accent. Allen argues that dynamic accent does not always result in reduction (cf. syllable counting languages vs tact counting languages; Lotman 1998: 1859), and he also emphasizes the fact that reductions take much more time to develop than the period under discussion.

9 "The nature of the prosody, indeed, is that it raises or falls; generally, it can be observed in the pitch of the voice, so that if all the syllables would be pronounced with the same pitch, there would be no accent".

10 "The nature itself, as if modulating human speech, placed an acute tone in every word". 
possibility that in classical period a peculiar situation existed, where popular language had dynamic accent, while educated classes spoke Latin with melodic accent. Such situation could be explained by the enormous influence of the Greek language and culture on Roman intellectual elite. ${ }^{11}$

There is no doubt, however, that by the 5th century at the latest, Latin had developed dynamic accent: the phenomenon was then described also by the grammarians, e.g. Pompeius: "Illa syllaba plus sonat in toto verbo, quae accentum habet ${ }^{12, " ~(G r a m m a t i c i ~ L a t i n i ~} 5$. 126. 31).

An important argument in favour of dynamic word-accent is provided also by Latin poetry which shows clear regularities in concurrences of strong positions and word-accents. E.g., for the Latin hexameter it is characteristic that in the first half of the verse accents do not concur with strong positions, while in the second half they do. Cf. Table 1, where the frequencies of concurrences between strong positions and accents are presented.

Table 1. The concurrences of word-accents in the Latin hexameter (De Neubourg 1986: 147).

\begin{tabular}{|l|l|l|l|l|l|l|}
\hline & I & II & III & IV & V & VI \\
\hline Ennius & 78.3 & 33.2 & 18.5 & 33.8 & 79.6 & 85.8 \\
\hline Cicero & 84.5 & 34.2 & 13.4 & 44.6 & 94.9 & 99.2 \\
\hline Lucretius & 76.3 & 41.9 & 21.7 & 47.9 & 93.9 & 97.7 \\
\hline Catullus & 73.5 & 28.2 & 11.0 & 61.5 & 91.2 & 99.5 \\
\hline Vergilius & 68.0 & 33.2 & 24.6 & 37.7 & 99.1 & 99.4 \\
\hline Horatius & 71.4 & 30.3 & 25.0 & 47.0 & 96.9 & 96.9 \\
\hline Ovidius & 79.7 & 36.6 & 14.6 & 47.7 & 99.5 & 99.9 \\
\hline
\end{tabular}

Hence, in hexameters, a strong accentual conflict evolved between the first and the second half (although it has to be pointed out, that the first foot has also a strong tendency towards accentual structure). Such phenomenon is usually explained by the Latin accentual rules. Since there is an obligatory word-end at the end of the verse line, the placement of accents is not incidental, but depends on the configu-

${ }^{11}$ Cf., e.g., the Swedish language that has melodic accent and the Fenno-Swedish language that has dynamic accent.

12 "The syllable, which carries an accent, is the most sonorous in the whole word." 
ration of heavy and light syllables before the word-end. The strong position in the sixth foot had to be filled with the heavy penultimate syllable of a word which, according to the Latin accentual rules, always carried the stress. The accentuation of last two feet could have been avoided with a monosyllable at the end of a line, thus filling a strong position in a sixth foot with an unaccented ultimate syllable of a word, but monosyllabic words at the end of a line were avoided and even regarded as a serious error of versification (De Neubourg 1986: 71). For example, Servius comments on the end of a Vergilian verse procumbit humi bos with harsh words: est hic pessimus versus in monosyllabum desinens. ${ }^{13}$

There exist also opinions according to which such rhythmical contrast was a deliberate artifice of hexametrical poets. Since this verse form was adapted from the language of different phonological basis, the quantitative rules had to be learned as well, and it is only natural that a poet was in such case also aware of the relationship between accent and quantity in his versification. The same applies also to his educated readers. However, more interesting is the reaction of the less educated hearers, who had not learned the quantitative rules: could they grasp the quantitative versification which, to a large extent, was not supported by the configuration of accent? Sidney W. Allen (1973: 339) assumes that a less sophisticated hearer might have perceived the quantity of orally arrested syllables only so far as they were directly connected with accent, and for him the quantity of final syllables was, thus, irrelevant: e.g. the reader may have not been aware of the opposition of final syllables in tange and tangent and the equivalence of the latter form with the form tangess (however, S. W. Allen admits that the length of thoracically arrested syllables that were often connected e.g. with morphological endings, were perceived also independently ${ }^{14}$; ibid.). The Roman anonymous epigrams (Carmina Epigraphica Latina, further CEL) include hexametrical poems which

${ }^{13}$ It is the worst verse, ending with a monosyllable.

14 Extremely interesting evidence is here provided by the dialogue verses by Plautus and Terence, where heavy syllables occur freely in every position, incl. those where in Greek verse a light syllable was obligatory. A closer examination reveals there is a tendency for the weak position to be filled by not just any heavy syllable, but by an unaccented morphological ending. On the one hand, it could certainly be explained by the avoidance of the concurrences of word-ends and metrical boundaries, which results in a word-end usually occurring inside a feet. On the other hand, we could go even further than W. S. Allen and ask: were the independent thoracically arrested syllables perceived the same way as those thoracically arrested syllables that were directly connected with accent, or were they perceived somehow differently? 
interpret both metrical and prosodical rules with great freedom: often the correct pattern characterizes only the end of a line - if not quantitatively, then at least accentually (Allen 1973: 346-347). We can assume that in such cases the authors were less educated poets who were not aware of Greek prosody. Such versification is well illustrated by the following fragment (CEL 470. 1-4):

Quat valeas abeas pascas, multos tu habebes amicos.

si haliquit casu alite[r] aduxerit aster,

aut ili Romai frater es aut tu peregre heris

et vocas acliva. quo si tu non nosti amicos...

Even more freedom is seen in the following example, where also the end pattern is often incorrect (CEL 331):

Conrigi vix tandem quod curvom est factum crede.

Credis quod deicunt? non sunt ita. ne fore stultu.

De incerto certa ne fiant, si sapis, caveas.

De vero falsa ne fiant iudice falso.

Est equos perpulcer, sed tu vehi non potes istoc.

Est vi [p]er [c]livom. qua vi[s] sequi, non [datur ista.

Formidat omnes. quod metuit, id sequi satiust.

Hostis incertus de certo, nisi caveas.

Iubeo et is ei si fecerit, gaudebit semper...

There are numerous violations of both metrical and prosodical structure in this example. Thus, e.g. caveas at verse end, as well as a foot containing a cretic word-group (e.g. est equos in the fifth verse line) or a foot containing a tribrachic word-group (e.g. iubeo et in the last verse line) never would have been admitted in classical hexameter.

It has to be pointed out that there are no such examples in Greek hexametrical poetry: Greek poets follow the metrical rules exactly, admitting, occasionally, some prosodical licences (Allen 1973: 346347).

The interference of accentual principle is seen even more clearly in early Latin drama, especially in iambic and trochaic verse. Namely, the unaccented syllables tend to fill the weak positions, while in strong positions prevail the accented syllables. Since in early iambic and trochaic verse heavy syllables are allowed also in weak positions, 
accent plays often an important role in verse rhythm. ${ }^{15}$ Cf., e.g., Terence, Adelphoe 144ff:

Quom placo, advorsor sedulo et deterreo, tamen vix humane patitur; verum si augeam, aut etiam adiutor sim eius iracundiae, insaniam profecto cum illo. Etsi Aeschinus non nullam in hac re nobis facit inuriam.

Such tendency is characteristic to about $80 \%$ of Plautian and Terentian iambic and trochaic verse lines.

Let us analyse briefly the law of brevis brevians or correptio iambica which, while unfamiliar to Greek prosody, was quite common in Latin poetry, especially in early iambic and trochaic versification. Traditionally, it is interpreted as a shortening of an unaccented heavy syllable in the case when a neighbouring syllable carries an accent. Cf., e.g., Terence, Eunuchus 8:

ex Graecis bonis Latinas fecit non bonas

where in bonis the final heavy syllable has become shortened under the influence of the first accented syllable.

There have been extensive disputes about the actual meaning of this phenomenon. E.g. Sandro Boldrini (1999: 39-46) suggests that it did not mean an actual shortening of a syllable, instead, a syllabic group maintained its quantities, being in certain cases perceived as an iambic unit. The other possible explanation is that in certain cases the accentual principle may have started to dominate the quantitative one, becoming the primary factor in versification.

W. S. Allen (1973: 163-186) represents the viewpoint, according to which the iambic shortening is related not only to verse prosody, but characterizes the phonology of natural language as well ${ }^{16}$. In order to prove his opinion, he analyses the accentual matrices of the Latin language and draws some important conclusions. For one, he argues that most likely there was no actual basis in Latin phonology for the

15 The opposite viewpoint is supported by e.g. Kenneth M. Abbot (1944), according to whom the concurrences of accents and strong positions can fully be explained by Latin accentual rules.

${ }^{16}$ On the other hand, e.g. W. Beare sees the reason for iambic shortening in the difficulty to provide an unaccented syllable, though quantitatively strong, with the necessary metrical force (Beare 1968: 324), i.e. for Beare, this phenomenon is exclusively related to versification. 
equivalence $-=\cup$. Traditionally, it has been stated that there is a tendency in Latin toward a binary rhythm in which light syllables occur in pairs: e.g. the formation of perfect of the II conjugation, where the form $-u i$ is characteristic to verbs which have a root of a single light syllable, e.g. moneo $>$ monui, deceo $>$ decui, while the verbs which have a root with a heavy syllable, have other formations, e.g. augeo $>$ auxi, mulceo $>$ mulsi etc. Similarly, the infinitive of the verbs of the IV conjugation which have a root consisting of one light syllable, is formed with a short $\breve{l}$ (which changes into $\breve{e}$ before $r$; traditional school grammar places such verbs in the III conjugation), e.g. capio, capere; facio, facere; while the verbs which have longer roots, i.e. consisting of one heavy or two light syllables, like audire, dormire, aperire, sepelire etc, have the infinitive form with long $\bar{i}$. W. S. Allen contends that there are also infinitives which can not be explained by the above-given logic. Namely, the IV conjugation includes also verbs like impedire, fulgurire which have infinitives with long $\bar{l}$, but the final syllable of the root is short. S. W. Allen suggests that the form capere is a result of the light and accented final syllable of a root which is not typical to ìre-infinitives, cf. e.g. audire, aperire, impedire, etc. ${ }^{17}$ It means that this phenomenon has not only quantitative, but also accentual basis. Thus, in the case of Latin it is not correct to speak of the purely quantitative equivalence $-=u$, which has no accentual basis, but rather of the equivalence $\dot{=}=\dot{v}$. This viewpoint is rather strongly supported by the evidence of the early Latin scenic verse.

The explanation for iambic shortening could be provided namely by the accentual matrices preferred in the natural language. W. S. Allen states that words with the pattern of $\dot{-}$ - were in certain conflict with the accentual rules which had been established by the historical times (cf. e.g. $\breve{e g} \bar{o}, m \breve{o} d \bar{o}$ etc, which during the early literary period still had a heavy final syllable, and *mălĕ, *bĕnĕ etc, the final vowels of which had been shortened in preliterary times). Thus, the tendency to shorten the second syllable occurred, and as a result its thoracic arrest disappeared and a normal disyllabic accentual matrix was established (while the words with a heavy penultimate syllable maintained the quantity of the final syllable, e.g. longē).

${ }^{17}$ It must be noted that there are also different examples which are not discussed by W. S. Allen, cf. e.g. venio, venire; salio, salire etc. 
The main features of the prosodic system of Latin can be summarized as follows.

(1) As in Greek, both vowels and consonants can be prosodically significant. The syllables can be unarrested (i.e. open syllables containing short vowels, e.g. -que), but also arrested either orally (e.g. closed syllables containing short vowels, e.g. id), or thoracically (i.e. containing long vowels or diphthongs, e.g. $m \bar{e}$; Allen 1973: 129). As in Greek, the hypercharacterization occurs here as well.

The phonological opposition of arrested and unarrested syllables, i.e. the distinction of quantities, is a very important feature of Latin versification.

(2) The reduction of unaccented syllables that was characteristic to the preliterary period, but also to the popular Latin and late classical Latin, e.g. officina $<*$ opificina, auceps $<*$ avicaps.

(3) The occurrences of enclitical and proclitical phenomena (typologically, this feature is relevant in the comparison with syllablecounting languages, where these phenomena, in general, do not occur).

(4) The dynamic accent which in the classical period may have been replaced with the melodic accent in the language of more educated classes.

(5) As is characteristic to languages that have reduction of unaccented syllables, the smallest prosodical unit was not a syllable, but a stress unit (tact). Consequently, Latin belongs typologically to the stress-counting languages (cf. Pike 1949: 34-36), and the distinguishing factor of prosodemes is force.

(6) Characteristic to Latin is also the gradation of accentual intensity, i.e. there developed secondary accentuation.

(7) When vowels meet, the following options are possible:

(a) elision, i.e. the final syllable of the word is not pronounced if it is followed by a word beginning with a vowel. In Latin the final $m$ was weak (it may have been slightly nasal as in French), and the syllable ending with $m$ was elided. If the second word in a hiatus was es or est, then the elision took place so-to-say "backwards" (so-called prodelision), i.e. the beginning of the second word was not pronounced, e.g. dictum est $=$ dictumst;

(b) synizesis, i.e. two or more vowels belonging to different syllables could form one heavy syllable by amalgamation of vowels; this can happen with ea (e.g. eadem), eo (e.g. deorum), ei (e.g. deinde), eu (e.g. meum), ie (e.g. diebus), ua (e.g. tua), ue (e.g. fuere), ui (e.g. fuisti), uo (e.g. suo); 
(c) the consonantalization of $i$ and $u$, e.g. the famous example from the beginning of the Aeneid: Laviniaque venit (on the other hand, the opposite can occur as well, cf. in silvae [Horatius Od. I 23.4] $v$ has been vocalized into $u$ );

(d) hiatus, in which case both vowels retain their initial values. Generally, this is avoided, but exceptions may occur, usually at a caesura or diaeresis.

\section{Versification systems in Latin poetry}

The described prosodical system provides a basis for considerably more versification systems than in Greek. Both in Latin and in Greek the versification can be based on quantitative-syllabic principle (e.g. hexameter, pentameter, iambic trimeter etc) and the syllabic-quantitative principle (the Aeolian metrics has been widely exploited also in Roman lyrical poetry). In addition to these, there exist, at least in preliterary Latin, but most likely later as well, also possibilities for such versification systems that are based on accentual principle or its participation. The limited bulk of Saturnian verses (a little more than 120 verse lines), which may be the only original Latin verse form (i.e. it evolved before the Greek versification started to have major influence on the Latin versification), seems to prove that these possibilities have been realized in actual poetry - most of them make sense as accented verse. The so-called versus quadratus which is the Latin version of Greek trochaic tetrameter, also shows clear evidence of accentual component (Gasparov 1989: 70). Although in classical Latin a versification based primarily on accentual principle never really evolved, several peculiar versification systems developed, in which the principles of quantity, accent and syllabification were united. Thus, the Latin versification could be compared e.g. with versification systems which have been created to translate ancient poetry into Estonian (e.g., by Ervin Roos or Ain Kaalep) and which combine all the above-mentioned principles (Lotman 1998: 2064-2065).

In Roman poetry the following versification systems can be observed. 


\subsection{Purely quantitative versification system}

This was most likely characteristic to the Saturnian verse (unfortunately, there have not remained enough verse lines to make any fundamental conclusions about its structure). In the case of the Saturnian verse neither the quantity nor the syllabics were relevant, but only the number of accent. Two main types of the Saturnian verse have been distinguished: the so-called maior which had five accents and minor which had four accents. The structure of the Saturnian verse is illustrated with the following schemes (Lotman 1998: 1869):

$$
\text { \&AAAA\& }
$$

and

$$
\text { \&AAAAA\& }
$$

where one stress unit or tact corresponds to position A.

$$
\text { Cf., e.g., CEL 6: }
$$

Honc oino / ploirume / cosentiont / R[omane

duonoro / optumo / fuise / viro,

Luciom / Scipione. / filios / Barbati

consol / censor / aidilis / hic fuet / a[pud vos.

hec cepit / Corsica / Aleriaque / urbe,

dedet / Tempestatebus / aide / mereto[d / votam

Theoretically also accentual-syllabic and syllabic-accentual versification systems are possible, moreover, they might have been actually realized in popular poetry (cf. e.g. versus quadratus), but there have remained too few possible examples to draw any specific conclusions.

\subsection{Syllabic-quantitative versification system}

The Aeolian verse metres were quite popular among the classical Roman poets. Although here as well, as in most Latin verse forms, accents tended to occur in certain positions, it should not be considered metrical, but rather rhythmical regularity. Syllabic-quantitative are e.g. the glyconics in Seneca's tragedy Medea $(75 \mathrm{ff})^{18}$ :

18 The Aeolian metres in Latin poetry are not always syllabic-quantitative: occasionally, they allow resolutions or contractions, cf. the glyconic by Seneca (Oed. 891): vita decurrens via, where two light syllables have been replaced by one heavy (Raven 1965: 141). It has to be noted that resolutions were admitted in Aeolian metres already by Sophocles and Euripides (West 1982: 116). 


\author{
vincit virgineus decor \\ longe Cecropias nurus, \\ et quas Taygeti iugis \\ exercet iuvenum modo \\ muris quod caret oppidum \\ et quas Aeonius latex \\ Alpheosque sacer lavat
}

where the natural word-accent often coincides with short positions, e.g., virgineus, iuvenum, etc.

\subsection{Quantitative-syllabic versification system}

This is typical to certain Ionian metres in Latin poetry, e.g., bacchiac and cretic metres which are quite common in early drama. Cf., e.g., the scheme of bacchiac tetrameter (Raven 1965: 123-124):

$\& \& A B B \& A B B \& A B B \& A B B \& \&$ where the following quantitative-syllabic rules apply:

(1) To the position A corresponds one light syllable, one heavy syllable or the sequence of two light syllables, but the latter can occur only if the other positions of a foot have been filled with one syllable.

$$
\begin{aligned}
& A \rightarrow \cup \\
& A \rightarrow- \\
& A \rightarrow \cup \cup / . . \ldots
\end{aligned}
$$

(2) To the position B corresponds one heavy syllable or the sequence of two light syllables, but the latter can occur only if the other positions of a foot have been filled with one syllable.

$$
\begin{aligned}
& \mathrm{B} \rightarrow- \\
& \mathrm{B} \rightarrow \cup \cup / \times \ldots- \\
& \mathrm{B} \rightarrow \cup \cup / \times-\ldots
\end{aligned}
$$

Cf. e.g. Plautus, Captivi 226ff:

Adcurate agatur, docte et diligenter.

Tanta incepta res est: hau somniculose hoc Agundumst. TY. Ero ut me voles esse. PH. Spero.

TY. Nam tu nunc vides pro tuo caro capite carum offerre [me] meum caput vilitati.

There exists also a number of versification systems in Latin which combine quantity, accent and syllabics. 


\subsection{Quantitative-syllabic-accentual versification system}

In this system, the main organizer of verse structure is quantity, which determines the syllabics of a verse line. Certain positions are characterized by an accentual constant. Such versification is typical to, e.g., Latin hexameter (its accentual regularities have already been discussed above). Cf. e.g. Vergilius, Aeneid 494ff:

Haec dum Dardanio Aeneae miranda videntur dum stupet obtutuque haeret defixus in uno, regina ad templum, forma pulcherrima Dido, incessit magna iuvenum stipante caterva.

\subsection{Quantitative-accentual-syllabic versification system}

This is, above all, typical to early scenic iambic and trochaic metres. E.g. the structure of Latin iambic trimeter (senarius) has been organised with quantitative, syllabic and accentual principle.

$\& \& \& A B \& A B \& \& A B \& A B \& \& A B \& A B \& \& \&$

I Syllabic principle.

The main syllabic rule (which is not violated in Greek verse) is the following: one syllable or a sequence of two syllables corresponds to each position, but the latter one can occur only if the other position of a foot is filled with one syllable.

$$
\begin{aligned}
& \mathrm{A} \rightarrow \mathrm{X} \\
& \mathrm{A} \rightarrow \mathrm{XX} / \ldots \mathrm{X} \\
& \mathrm{B} \rightarrow \mathrm{X} \\
& \mathrm{B} \rightarrow \mathrm{XX} / \mathrm{X} \ldots
\end{aligned}
$$

In texts by Plautus and Terence this principle is occasionally violated and especially in the first feet proceleusmatics are allowed (Raven 1965: 51-53). Still, in most cases this principle appears to be an important regulator of the syllabism in a verse line.

II Quantitative principle.

The quantitative rules are closely related to the syllabic rules, hence, the quantitative-syllabic correspondance rules are as follows:

(a) One heavy syllable, one light syllable or a sequence of two light syllables corresponds to position A, but the latter one can occur only if a strong position is filled with one syllable.

$$
\mathrm{A} \rightarrow \underline{\cup}
$$




$$
\begin{aligned}
& \mathrm{A} \rightarrow \cup \cup / \ldots X \\
& \mathrm{~B} \rightarrow- \\
& \mathrm{B} \rightarrow \cup \cup / X \ldots
\end{aligned}
$$

(b) One heavy syllable or a sequence of two light syllables corresponds to position $\mathrm{B}$, but the latter one can occur only if position A is filled with one syllable. The line which is organised by quantitative-syllabic rules, is e.g. Terence, Adelphoe 143:

Me aegre pati illi nolui. Nam itast homo.

The word-accent in this case is irrelevant, the number and the quantity of syllables are the only constituents of iambic structure.

III Accentual principle.

The third set of rules involves accentual rules:

(a) word-accents tend to occur in strong positions;

(b) word-accents tend to be avoided in weak positions;

(c) in resolved feet word-accent tends to occur in the first syllable of the resolved strong position, i.e. the most common form in iambic verse is $x \dot{x} x$, but in trochaic verse $\dot{x} x x$. About $80 \%$ of analysed iambic and trochaic verse lines are in correspondence with this rule, e.g. Terence, Adelphoe $804 \mathrm{ff}$ :

Communia esse amicorum inter se omnia.

DE. Facete! nunc demum istaec nata oratiost.

MI. Ausculta paucis nisi molestumst Demea!

Principio, si id te mordet, sumptum filii

quem faciunt, quaeso hoc facito tecum cogites...

IV Accentual-quantitative-syllabic rules.

And finally, the most complicated one is the accentual-quantitativesyllabic rule. Namely, on certain occasions, when the stressed syllable occurs in a strong position, the quantity of the rest of the syllables in a given foot may become irrelevant and the foot may become the subject to accentual rules. This rule causes e.g. the phenomenon which is traditionally treated as iambic shortening. Cf. e.g. the accentuation in the third foot of iambic verse in Ter. Adelph. 4:

Indicio de se ipse erit, vos eritis iudices.

or the accentuation in the first foot of trochaic verse in Plautus, Amphitruo 281: 
Eam quoque edepol etiam multo haec vicit longitudine.

But the so-called iambic shortening is not the only case where the accentual structure prevails over quantity. There are numerous other examples, e.g., Ter. Adelph. 106:

Iniuriumst, nam si esset unde id fieret,

where in the fifth foot instead of iambus we find a trochee, but the accentual structure still remains iambic.

As in hexametrical verse, also in iambic trimeter the rhythmical regularities of the last two feet are different from the first half of the verse. However, here the situation occurs, actually, the other way round: the end of the line has a tendency to quantitative structure, while the middle part of a verse has clear accentual structure.

The situation where different parts of verse structure are subject to different mechanisms of versification, is not unique. The study of verse history reveals a number of analogical instances where verse structure is organised by several principles of versification, while some of them dominate at the beginning of the verse, others at the end of the verse.

First, such features are characteristic to the structure of IndoEuropean verse. It was an isosyllabic verse, i.e. the number of syllables was metrically relevant and the primary element of metrical structure was syllable. Thus, the verse was organised by the syllabic principle. Word-accent played no role whatsoever, i.e. there was no regularity in the arrangement of accented syllables. On the other hand, quantity was relevant to some degree: there was a certain regularity in the alternation of heavy and light syllables. This regularity occurred mainly at verse ending, thus creating the so-called quantitative cadence, while the quantity of the first half of the verse was unregulated (West 1982: 2-3).

The second instance of such type is the medieval Latin verse. Approximately in the third century AD important phonological changes took place in the Latin language. The distinction between heavy and light syllables disappeared and thus the main opposition, which until then had served as the basis of versification, ceased to exist. Instead, new principles of versification evolved. The first step was to organize the syllabism of verse lines, hence creating the medieval Latin syllabic verse, where the main constituent of versification is the number of syllables. As a result, Latin verse starts to 
resemble its origin, the Indo-European verse. Next, its ending becomes regulated, but not quantitatively (as IE verse), but accentually. One of the earliest examples is St. Augustine's psalm against Donatists. Here are present all the features which are characteristic to medieval verse: isosyllabism, ${ }^{19}$ the irrelevancy of quantity, accentual verse ending, the emergence of rhyme (cf. also Gasparov 1989: 8790):

Honores vanos qui quaerit, / non vult cum Christo regnare,

Sicut princeps huius mali, / de cuius vocantur parte;

Nam Donatus tunc volebat /Africam totam obtinere;

Tunc iudices transmarinos / petiit ab imperatore...

There are several other examples, e.g., the Aeolian metres in ancient Greek versification or Estonian regisong - they both have quantitative-syllabic structure, but nevertheless, the first syllables in a line are quantitatively irrelevant. The closest example, of course, is the versification of early hexameter, where the accentual structure usually coincides with the quantitative structure of the fifth and sixth feet, but contradicts it at the beginning of a line.

Consequently, it can be said that in comparison with Greek verse, more rules participate in the organization of the early Latin verse. Although it is usually treated as a very liberated verse that is far simpler than its Greek model, we can not deny the complexity of its versification system which is the result of several combinatory versification principles.

\section{Conclusion}

1. The Greek language belongs typologically among the moracounting languages and thus provides possibilities for the emergence of purely quantitative verse, where structure is determined only by the number of moras; of the purely syllabic verse, where only the number of syllables is relevant; quantitative-syllabic verse, where in addition to the number of moras also their configuration is considered, and the syllabic-quantitative versification system, where the number of syllables is fixed and the quantity is subject to syllabics. There is no

${ }^{19}$ The isosyllabic structure is accomplished in the 3rd line with elision (totam obtinere) and in the 4th line with synizesis (petiit). 
purely quantitative or purely syllabic verse in actual Greek poetry; however, the syllabic-quantitative versification systems (the Aeolian tradition) and quantitative-syllabic versification systems (the Ionian tradition) were in use.

2. The Latin language, on the other hand, has a number of features, which characterize it as a stress-counting language. Since at the same time there exists also the opposition of heavy and light syllables, there are preconditions for the syllabic, accentual and quantitative principle, as well as for the combinations of these. The Roman literary heritage shows examples of purely accentual, syllabic-quantitative, quantitativesyllabic, as well as of several other combinatory versification systems.

\section{References}

Allen, William Sidney 1973. Accent and Rhythm. Prosodic features of Latin and Greek: A Study in Theory and Reconstruction. Cambridge: Cambridge University Press.

Abbot, Kenneth M. 1944. Ictus, accent and statistics in Latin dramatic verse. Transactions and Proceedings of the American Philological Asssociation 75: 127-140.

Beare, William 1968. The Roman Stage. London: Methuen.

Boldrini, Sandro 1999. Prosodie und Metrik der Römer. Stuttgart: B. G. Teubner.

De Neubourg, Leo 1986. La base métrique de la localisation des mots dans l'hexamètre latin. Brüssel: Paleis der Academiën.

Gasparov 1989 = Гаспаров, Михаил Л. 1989. Очерк истории европейского стихха. Москва: Наука.

Halle, Morris 1970. On Meter and Prosody. (Progress in Linguistics.) The Hague: Mouton.

Hogg, Richard M.; McCully, Chris B. 1987. Metrical Phonology: A Coursebook. Cambridge: Cambridge University Press.

Jakobson, Roman 1962. Selected writings I. Phonological studies. The Hague: Mouton.

- 1969. O cheskom stikhe (preimusshchestvenno v sopostavlenii s russkim). Providence: Brown University Press.

Kuryłowicz, Jerzy 1962 = Курилович, Ю. 1962 [1930]. Связь метрики с разговорным языком: Очерки по лингвистике. Москва: Изд. иностр. лит.

La Drière, James Graig 1943. Prosody: The Dictionary of World Literature. Shipley, J. T. (ed.). New York: The Philosophical Library.

Lehiste, Ilse 1970. Suprasegmentals. Cambridge: MIT Press.

Lotman, Mihhail 1998. Värsisüsteemidest (peamiselt eesti ja vene värsi näitel). Akadeemia 10: 1846-1874; 11: 2058-2078.

Martinet, André 1960. Éléments de linguistique générale. Paris: Armand Colin. 
Niedermann, Max 1945. Précis de phonétique historique du Latin. Paris: C. Klincksieck.

Otake, Takashi; Cutler, Anne 1999. Perception of suprasegmental structure in a nonnative dialect. Journal of Phonetics 27: 229-253.

Palmer, Leonard Robert 1954. The Latin Language. Norman: University of Oklahoma Press.

Pike, Kenneth Lee 1949. The Intonation of American English. Ann Arbor: University of Michigan Press.

Raven, David S. 1965. Latin Metre. London: Faber and Faber.

Stetson, Raymond Herbert 1951. Motor Phonetics: A Study of Speech Movements in Action. Amsterdam: North-Holland.

Trubetzkoy 2000 = Трубецкой, Николай С. 2000 [1939]. Основы фонолоzий. Москва: Аспект пресс.

West, Martin Litchfield 1982. Greek Metre. Oxford: Clarendon Press.

\section{Просодия и системы стихосложения античного стиха}

Задачей работы является описание просодических систем древнегреческого и латинского языков, а также анализ систем античного стихосложения. Типологически древнегреческий язык принадлежит к языкам моросчитающего типа, что создает естественные предпосылки для развития как чисто-квантитативного и чисто-силлабического, так и квантитативно-силлабического и силлабо-квантитативного стихосложения. В древнегреческой стихотворной практике чисто-квантитативный и чисто-силлабический стих не встречается, зато представлены силлабоквантитативная система стихосложения (эолийская традиция) и квантитативно-силлабическая (ионийская и дорийская традиции). В латинском языке имеется ряд признаков, позволяющих отнести его к языкам тактосчитающего ритма. Поскольку в нем имеется и оппозиция долгих и кратких слогов, можно говорить о естественных предпосылках для развития как силлабического, квантитативного и акцентного стихосложения, так и различных комбинированных вариантов. Сохранивниеся тексты могут быть отнесены к акцентному (сатурнов стих), силлабо-квантитативному (лирические строфы), квантитативно-силлабическому (гексаметр, ямбический триметр), а также к ряду переходных форм, сочетающих ударение, силлабику и квантитет.

\section{Antiikvärsi prosoodia ja värsisüsteemid}

Töö eesmärgiks on kirjeldada vanakreeka keele ja ladina keele prosoodilist süsteemi ning analüüsida värsisüsteeme, mis on vanakreeka ja ladina luulepraktikas realiseeritud. Kreeka keel kuulub tüpoloogiliselt moorasid loendava rütmiga keelte hulka ning seega on selles keeles olemas eeldused puhtkvan- 
titeeriva, puhtsüllaabilise, kvantiteeriv-süllaabilise ja süllaabilis-kvantiteeriva värsi jaoks. Vana-kreeka luulepraktikas puhtkvantiteerivat ja puhtsüllaabilist värssi ei leidu, seevastu on esindatud süllaabilis-kvantiteeriv värsisüsteem (aioolia luuletraditsioon) ning kvantiteeriv-süllaabiline värsisüsteem (joonia ja dooria luuletraditsioon). Ladina keelel on aga rida tunnuseid, mis määravad selle kuulumise takte loendava rütmiga keelte hulka. Kuna samas eksisteerib ka pikkade ja lühikeste silpide opositsioon, on ladina keeles olemas eeldused nii süllaabilise, kvantiteeriva, aktsendilise kui ka nendest kombineeritud värsisüsteemide tekkeks. Meie ajani on säilinud puhtaktsendilist, süllaabiliskvantiteerivat, kvantiteeriv-süllaabilist värssi ning samuti rida vorme, milles värsiehituslikeks komponentideks on nii sõnarõhk, süllaabika kui ka kvantiteet. 